\title{
Testicular and seminal evaluation of dogs naturally infected with Leishmania sp.
}

\section{Avaliação testicular e seminal de cães naturalmente infectados por Leishmania sp.}

\author{
Luanna Soares de Melo Evangelista ${ }^{1 *}$; Marcos Antônio Celestino de Sousa Filho²; \\ Marinna Nérica do Nascimento e Silva ${ }^{3}$; Georgia Brenda Barros Alves ${ }^{3}$; Rayssa \\ Maria de Araújo Carvalho ${ }^{4}$; Nair Silva Cavalcanti de Lira ${ }^{5}$; Joilson Ferreira \\ Batista $^{2}$; Ivete Lopes de Mendonça ${ }^{6}$; José Adalmir Torres de Souza ${ }^{6}$
}

\begin{abstract}
The objective of this study was to evaluate the testicular changes and detect the presence of Leishmania $\mathrm{sp}$. in the testicles and semen of dogs with Visceral Leishmaniasis (VL). The animals were obtained from the Zoonoses Control Department of Teresina, PI, and taken to the kennel of the Agricultural Sciences Center of the Federal University of Piauí, where they remained were maintained for two months and subsequently euthanized for testicles removal. Semen samples were collected from 12 dogs, 06 positive and 06 negative for VL. The following diagnostic techniques readouts were assessed for the sampled animals: testosterone dosage, immunohistochemistry (IMH), histopathology of the slides containing the testicular material, and seminal evaluation by polymerase chain reaction (PCR). Testosterone values remained within the normal range for the canine specie and did not differ statistically among the experimental groups but displayed lower serum concentrations than those of the control group. All the testicular and semen samples from the dogs were negative for VL as determined by techniques IMH and PCR, respectively. The results of testicle histopathology revealed the presence of several lesions with statistical difference among the experimental groups. Parasitized dogs with VL have testicular lesions that may compromise the reproductive efficiency of these animals.
\end{abstract}

Key words: Canine. Semen. Testicles. Visceral leishmaniasis.

\section{Resumo}

O objetivo deste estudo foi avaliar as alterações testiculares e detectar a presença de Leishmania sp. nos testículos e sêmen de cães com leishmaniose visceral (LV). Os animais foram obtidos da Gerência de Controle de Zoonoses de Teresina, PI, e levados ao canil do Centro de Ciências Agrárias da Universidade Federal do Piauí, onde permaneceram por dois meses e posteriormente foram submetidos à eutanásia para a remoção dos testículos. As amostras de sêmen foram coletadas de 12 cães, sendo 06 positivos e

1 Prof $^{\mathrm{a}} \mathrm{Dr}^{\mathrm{a}}$, Departamento de Parasitologia e Microbiologia, Universidade Federal do Piauí, UFPI, Teresina, PI, Brasil. E-mail: luannaufpi@gmail.com

2 Pós-Graduandos em Ciência Animal, UFPI, Teresina, PI, Brasil. E-mail: marcoscelestino90@gmail.com; joilsonvet@gmail.com

3 Médicas Veterinárias Autônomas, Drª . em Ciência Animal, UFPI, Teresina, PI, Brasil. E-mail: marinnannsilva@hotmail.com; georgiaveterinaria@hotmail.com

4 Prof $^{\mathrm{a}} \mathrm{Dr}^{\mathrm{a}}$, Faculdade Integral Diferencial, FACID DeVry, Teresina, PI, Brasil. E-mail: rayssacarv@gmail.com

5 Prof ${ }^{\mathrm{a}} \mathrm{Dr}^{\mathrm{a}}$, Universidade Federal Rural de Pernambuco, UFRPE, Garanhuns, PE, Brasil. E-mail: naircl@hotmail.com

6 Profs. Drs., Departamento de Clínica e Cirurgia Veterinária, UFPI, Teresina, PI, Brasil. E-mail: ivetemendonca54@gmail.com; adalmir@ufpi.edu.br

* Author for correpondence 
06 negativos para LV. Nas amostras dos animais, foram realizadas as seguintes técnicas de diagnóstico: dosagem de testosterona, imunohistoquímica (IMH), histopatologia das lâminas contendo o material testicular e avaliação seminal por reação em cadeia pela polimerase (PCR). Valores de testosterona permaneceram dentro do intervalo normal para a espécie canina, não diferindo estatisticamente entre os grupos experimentais, porém apresentando concentrações séricas mais baixas do que o grupo controle. Todas as amostras testiculares e de sêmen dos cães foram negativas para LV, conforme determinado pelas técnicas IMH e PCR, respectivamente. Os resultados da histopatologia dos testículos revelaram a presença de várias lesões com diferença estatística entre os grupos experimentais. Os cães parasitados com LV apresentam lesões testiculares que podem comprometer a eficiência reprodutiva desses animais.

Palavras-chave: Canino. Sêmen. Testículos. Leishmaniose visceral.

\section{Introduction}

Visceral Leishmaniasis (VL) is a tropical disease considered a serious problem to global public health. In Brazil, VL is caused by the protozoan species Leishmania (Leishmania) chagasi (BRASIL, 2014). Dogs are the most important reservoirs of the parasite in urban areas, mainly owing to their proximity to human beings. Transmission usually occurs in the presence of the vector, which is infected after feeding on blood of an parasited animal or man, ingesting amastigote forms present in the dermis (KAMHAWI, 2006).

Although this is the main form of contamination, there are reports of transmission in the absence of the vector, such as by blood transfusion in dogs (FREITAS et al., 2006) and needles and syringes sharing among drugs users (BOSCH et al., 2002). Vertical transmission of Leishmania sp. between humans has already been described (LOW et al., 1926). In addition, there is a venereal transmission reported between an infected man and his wife in area free of the disease and vectors (SYMMERS, 1960). In dogs, sexual transmission has also been considered likely (DUBEY et al., 2005; SILVA et al., 2009; BENITES et al., 2011), with reports demonstrating the elimination of Leishmania sp. in the semen of VL-positive dogs evaluated by polymerase chain reaction (PCR) (DINIZ et al., 2005; AMARA et al., 2009; SILVA et al., 2014).

The PCR technique is a very sensitive method for the detection of Leishmania sp. amastigotes in seminal samples and the genital system tissues of dogs (SILVA et al., 2008). In addition, pre-existing inflammatory processes can recruit macrophages containing Leishmania sp., which can cause epididymitis, orchitis, and testicular degeneration (DINIZ et al., 2005). It may also decrease serum testosterone levels (COSTA et al., 2015), compromising the reproductive and spermatic quality of diseased animals. Dogs naturally infected with Leishmania sp. may have testicles apparently unchanged but possess several histologically apparent injuries, which vary according to the animal parasitic load (AMARA et al., 2009).

Currently new research has been seeking information about the elimination of the parasite, as assessed the semen of dogs with VL and the possibility of sexual transmission. Thus, this work aimed to evaluate the testicular changes and the presence of Leishmania sp. in the testicles and semen of naturally infected dogs.

\section{Material and Methods}

The Animal Experimentation Ethics Committee of the Federal University of Piauí (UFPI) analyzed and approved this work under protocol number 003/2014.

Mixed breed male dogs (SRD) (12) were obtained through the Zoonoses Control Department (GEZOON) of Teresina city, Piauí state. Dogs were then taken to the kennel of the Agricultural Sciences Center of the Federal University of Piauí (CCA/ UFPI), where they were maintained from February to April 2014. 
Dogs with positive serological and parasitological diagnosis for VL (6), being two asymptomatic and four oligosymptomatic (up to three clinical signs) were part in group $01(\mathrm{GI})$ and six negative dogs the group 02 (GII), which was considered the control group. The disease was serologically confirmed by TRDPP ${ }^{\circledR}$ and ELISA, using commercial BioManguinhos "kits", following the manufacturer's recommendations. Parasitological results were determined by the detection of Leishmania sp. amastigotes via aspiration of popliteal lymph nodes and dogs bone marrow, on blades made and stained by the GIEMSA method. Additionally, detection of Leishmania sp. promastigotes was achieved through the sowing of aspirations of popliteal lymph nodes and bone marrow in NNN culture medium enriched with Schneider's medium. Culture media was placed in the Incubator Chamber B.O.D., where three optical microscopy readings were obtained, on the $5^{\text {th }} 7^{\text {th }}$ and $10^{\text {th }}$ days after sowing, confirming the positivity of disease in the animals sampled.

Blood samples for testosterone dosage were obtained from all animals during the first week of the experiment, in the morning. Blood samples were collected from the jugular or cephalic vein of the animals and stored in vacutainer tubes without anticoagulant. After collection, the samples were centrifuged at $1.500 \mathrm{rpm}$ for 10 minutes and the blood serum packed in $1.5 \mathrm{~mL}$ microtubes, previously identified and frozen at $-20^{\circ} \mathrm{C}$ until the time of analysis. Testosterone dosages were analyzed in the Laboratory of Physiological Sciences, CCA/ UFPI and were determined by radioimmunoassay (RIA), using commercial "kits" (Coat-A-Count Total Testosterone, DPCR, Diagnostic Products Corporation, Los Angeles, CA, EUA), following the manufacturer's recommendations and expressed in $\mathrm{ng} / \mathrm{mL}$. The amount of testosterone present in the sample was determined from a calibration curve accompanying the commercial "kit".

Seminal samples were collected using the digital manipulation technique during the morning period. The first and last sperm fractions were discarded, maintaining only the sperm rich fraction. These samples were refrigerated and frozen at $-20^{\circ} \mathrm{C}$ until the PCR analysis was performed. The DNA extraction was performed at the Animal Health Laboratory (LASAN) by the phenol:chloroform:isoamylic method $(25: 24: 1)$. Then, $100 \mu \mathrm{L}$ of the semen was added to a $1.5 \mathrm{~mL}$ microtube containing $175 \mu \mathrm{L}$ of TNE (Tris, $\mathrm{NaCl}$, and EDTA), $10 \mu \mathrm{L}$ of proteinase $\mathrm{K}(20 \mathrm{mg} / \mathrm{mL})$, and $50 \mu \mathrm{L}$ of $4 \%$ SDS then kept warm in a water bath at $56^{\circ} \mathrm{C}$ for 1 hour. Then, 400 $\mu \mathrm{L}$ of phenol:chloroform:isoamylic $(25: 24: 1)$ was added to the sample. The solution was centrifuged at $13.000 \mathrm{rpm}$ for 10 minutes. After this procedure, the aqueous phase was transferred to another microtube and $400 \mu \mathrm{L}$ of chloroform: alcohol-propyl (24:1) was added. Centrifugation was then repeated. The supernatant was transferred to another microtube, $100 \mu \mathrm{L}$ of $6 \mathrm{M}$ sodium acetate and $100 \mu \mathrm{L}$ of absolute ethyl alcohol were added, the sample was centrifuged again, and then the whole supernatant was removed leaving only the "pellet". Cold $70 \%$ ethyl alcohol $(400 \mu \mathrm{L})$ was added and after further centrifugation, the tube was carefully inverted on absorbent paper. Then, the sample was resuspended in $50 \mu \mathrm{L}$ of TE (Tris-EDTA). After quantification, the DNA was stored at $-20^{\circ} \mathrm{C}$ until PCR was performed.

PCR analysis were performed at the Animal Pathology Laboratory, CCA/UFPI targeted a 100 bp conserved region of Leishmania kinetoplast DNA. The sequences of the primers used were as follows: VL1 (5'-ACGAGGTCAGCTCCACTCC-3') and VL2 (5'-CTGCCACGCCTGTGTCTAC-3') produced from the specific DNA sequence for the Donovani complex (PIARROUX et al., 1993). During PCR, $5 \mu \mathrm{L}$ of the GoTaq ${ }^{\circledR}$ Green Master Mix reagent (Promega Corporation, cat. M7122. Madison, WI. USA) was used, $1 \mu \mathrm{L}$ of the sample DNA and $1 \mu \mathrm{L}$ of each primer. As a positive control, a sample of bone marrow from infected dog with Leishmania chagasi was used. DNA from a dog negative for the disease was used as the negative control. Sample amplification was performed 
under the following thermal conditions: Initial denaturation at $94^{\circ} \mathrm{C}$ for 4 minutes followed by 35 cycles with denaturation temperature at $94^{\circ} \mathrm{C}$ for 1 minute, primer binding at $55^{\circ} \mathrm{C}$ for 1 minute, extension at $72^{\circ} \mathrm{C}$ for 1 minute, and final extension at $72^{\circ} \mathrm{C}$ for 5 minutes in the "Life Pro Thermocycler" thermal cycler. Subsequently, $3 \mu \mathrm{L}$ of reaction product was mixed with $2 \mathrm{x}$ sample buffer $(0.025$ $\mathrm{g}$ of bromophenol blue, $0.025 \mathrm{~g}$ of xylenecyanol and $15 \%$ of ficol diluted in ultrapure water) and subjected to $1.5 \%$ agarose gel electrophoresis at $100 \mathrm{~V}$ for one hour. The bands were visualized after staining by ethidium bromide with the aid of a UV transilluminator (Bio Agency) and photo documented (Bio - Imaging Systems).

At the end of the study, the negative animals were castrated and the positive animals were euthanized according to Resolution $\mathrm{N}^{\circ}$. 714 of June 20, 2002, of the Veterinary Medicine Federal Council, which deals with the procedures and methods for animal euthanasia. Thus, testicles fragments were removed for immunohistochemistry (IMH) and histopathology.

The testicles were analyzed macroscopically based on criteria such as size, consistency, mobility and the presence of lesions. Fragments were removed from these organs to prepare microscopy slides. These fragments were preserved in $10 \%$ neutral buffered formalin solution with $0.01 \mathrm{M}$ phosphate at $\mathrm{pH} 7.4$ and were used to perform the aforementioned exams.

The fragments of dog testicles, after being fixed, were processed and embedded in paraffin according to the routine techniques adopted at the
Laboratory of Animal Pathology, CCA/UFPI. Then, $5 \mu \mathrm{m}$ thick sections were stained with hematoxylineosin (H-E), Masson, PAS and PAMS to study the histopathological pattern of the tissue lesions. Testicular fragments were also processed to perform IMH technique with the polyclonal anti-Leishmania amazonensis antibody at a dilution of 1:400, amplified with the EnVision + anti-mouse system. The slides were analyzed under a standard light microscope. The semi-quantitative analysis was performed with an image analysis system (Optimas, Edmonds, CA, USA, Version 4.10), evaluated in random fields with a 0 to 5 scale interpretation where: $0=$ normal, $1=$ minimal or doubtful, $2=$ medium, 3 = moderate, $4=$ moderately severe and $5=$ highly severe.

Analysis of variance was performed using the program Assistat version 7.7 beta (pt), followed by a Tukey test to compare the means of the testosterone dosage analyzes. The results were expressed as mean \pm EPM. The semi-quantitative intensity analysis of histopathological changes in the testicles of dogs was performed using the Mann Whitney test. The significance level for the statistical analyzes was set at $\mathrm{p}<0.05$.

\section{Results}

In this study, no statistical difference was observed among the serum testosterone concentrations of GI and GII, as shown in Table 1. Testosterone levels remained within the normal range for canine specie in the studied animals, since blood reference values for male dogs vary from 1 to $7 \mathrm{ng} / \mathrm{mL}$. It was possible to observe serum decrease of this hormone in dogs the GI.

Table 1. Serum testosterone $(\mathrm{ng} / \mathrm{mL})$ concentrations in dogs positive and negative for VL ( $\chi \pm \mathrm{EMP})$.

\begin{tabular}{ccc}
\hline Parameters & GI - Positive & GII - Negative \\
\hline Testosterone $(\mathrm{ng} / \mathrm{mL})$ & $1.76 \pm 1.09^{\mathrm{a}}$ & $2.45 \pm 1.34^{\mathrm{a}^{*}}$ \\
\hline
\end{tabular}

*Equal letters on the same line do not indicate statistical difference $(\mathrm{p}<0.05)$. 
The results of the PCR of spermatic fraction revealed that all the samples evaluated were negative for Leishmania sp.
In IMH analyzes, no immunostaining was observed in any of the testicles of dogs with VL, as shown in Figure 1.

Figure 1. Testicles of dogs analyzed by IMH. (A) Testicle of a GII dog, considered as the control group. (B) Left testicle of a GI dog. (C) Right testicle of a GI dog - observe the presence of testicular lesions in testicles B and C, but without the presence of Leishmania sp. by immunostaining.

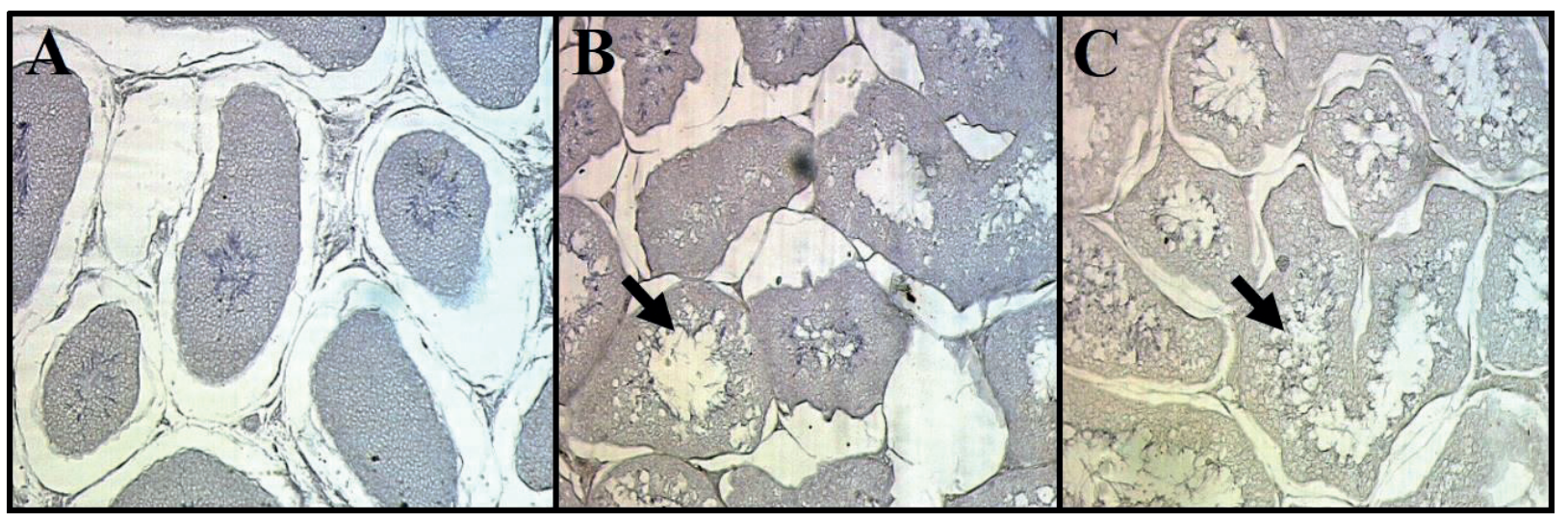

The testicles histopathology results evaluated in this study revealed the presence of several lesions, including statistical difference between the experimental groups (Figure 2). The main testicular alterations observed were severe oligospermia, diffuse and focal testicular degeneration, seminiferous epithelium atrophy and discrete inflammatory reactions, with presence of histiocytes. Figure 3 shows testicular damage in a dog with VL in the present study.

Figure 2. Semi-quantitative analysis of the intensity of histopathological changes in testicles of uninfected and infected dogs by Leishmania sp. $(\mathrm{p}<0.05)$.

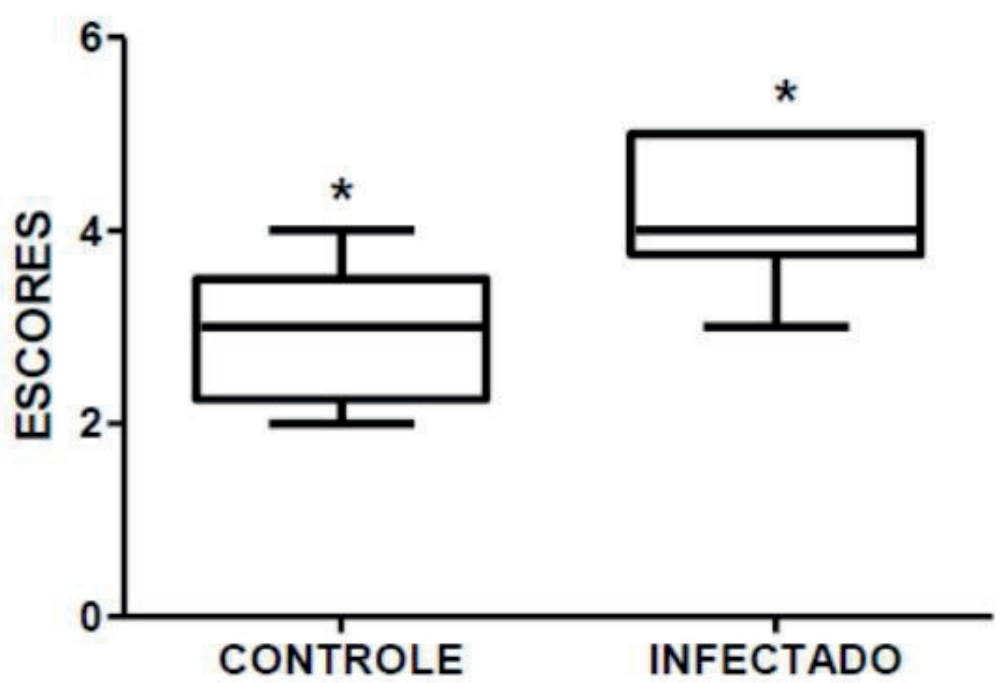

* Indicates significant differences between the experimental groups. 
Figure 3. Testicle of a dog naturally infected by Leishmania sp. evaluated by histopathology. The arrow shows testicular degeneration and atrophy of the seminiferous epithelium.

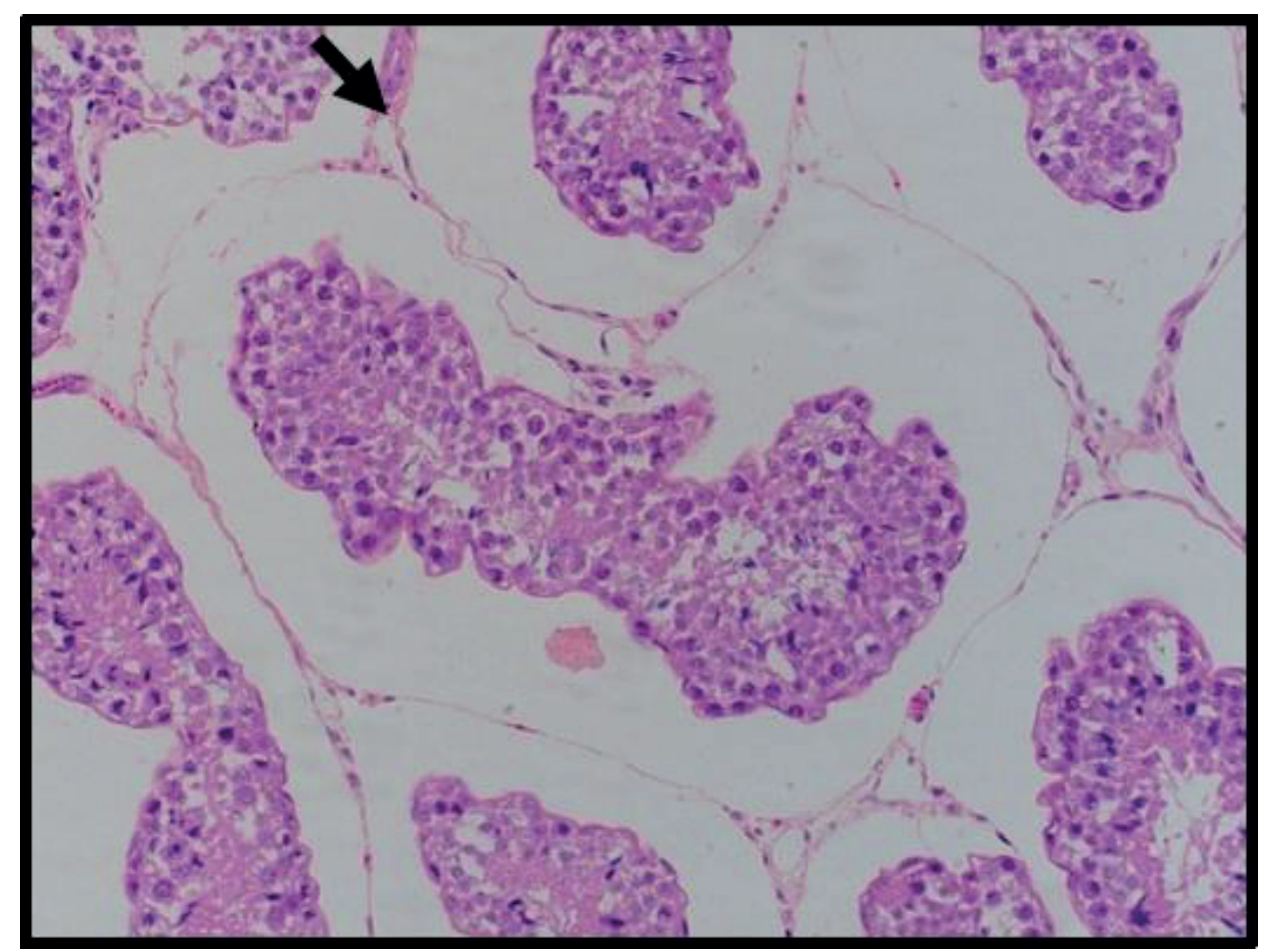

Although it was not possible to find macroscopic changes, histological results revealed severe oligospermia and testicular degeneration. Diffuse testicular degeneration was found in dogs infected with the parasite, while three negative animals had focal testicular degeneration with a mild inflammatory reaction.

\section{Discussion}

Control of testicular activity in dogs occurs mainly through the luteinizing hormone (LH) and follicle stimulating hormone (FSH). LH stimulates Leydig cells to produce testosterone, whose functions include promoting the development of the vas deferens and the epididymis, the maintenance of libido and the regulation of gonadotrophin releasing hormone $(\mathrm{GnRH})$ secretion by the hypothalamus and LH and FSH by the pituitary gland (HAFEZ; HAFEZ, 2004). Therefore, testosterone is essential at all stages of spermatogenesis.

Chronic inflammatory diseases are able to inhibit the gonadal steroidogenesis that can occur in VL, since it has been demonstrated that Leishmania sp. amastigote immunostaining in testicular macrophages of dogs shows an inflammatory lympho-histiocytic infiltrate (DINIZ et al., 2005). This infiltrate may be the result of parasitized macrophages that produce reactive oxygen species (ROS), causing damage to the mitochondrial membrane of Leydig cells and consequently inhibition of steroidogenesis (ALLEN et al., 2004) as well as testicular degeneration and atrophy, characteristics that can interfere in the production and secretion of testosterone by the testicles of diseased dogs. This may justify the decrease of this hormone in the dogs of the parasitized group this study.

Others studies did not observed any form of the parasite in the testicular tissue but detected them in 
the semen of dogs naturally infected by the PCR technique (DINIZ et al., 2005). They also found that the occurrence and intensity of inflammatory changes in the testicles due to VL was associated with clinical manifestations of the disease. This means that the presence of the parasites in the semen of symptomatic dogs was more evident than in asymptomatic, which may justify this research results, once the dogs were classified as asymptomatic or oligosymptomatic, with no apparent macroscopic lesions in the testicles, which probably revealed a limited number of parasites in these organs.

It is important to emphasize that the dogs classified as positive for VL by PCR in semen evaluation performed by Diniz et al. (2005) may have been inconsistent, once the evaluated animals were not conditioned to digital manipulation. Some seminal samples were composed mainly of the prostatic fraction, which contains little or no spermatic content, may have revealed Leishmania sp. coming from the prostate or prostatic fluid and not the spermatic fraction. In addition, they only used a semen sample from each dog evaluated, unlike this survey where four semen samples from each animal were used.

Other research evaluated the presence of parasites in the smegma and semen of symptomatic dogs (SILVA et al., 2014). This work concluded that the parasites present in the internal surface of the penis may favor venereal disease transmission, regardless of seminal deposition in the system genital of bitches, only by direct contact with the mucosa of the vulva and vagina. These data exclude possible sexual transmission exclusively via semen.

Others results revealed that, of the ten VL seropositive female dogs, one symptomatic and one asymptomatic presented intracytoplasmic amastigotes in inflammatory infiltrates in the vulva, detected by histopathology and confirmed by IMH (SILVA et al., 2008). In contrast, a significantly higher frequency of inflammation was associated with Leishmania immunostaining in the penis, epididymis, glans and prepuce of symptomatic dogs compared with asymptomatic dogs (DINIZ et al., 2005). This may justify the absence of immunostaining obtained in this research asymptomatic or oligosymptomatic GI dogs, confirming what the literature describes.

The histopathological finding of testicular degeneration observed in this work was characterized by the presence of some seminiferous tubules presenting loss of germinating cells, resulting in a reduction of the germinal epithelium and absence of spermatozoa in the luminal space. These data corroborate with others results (NUNES, 2008). In parasitized dogs, testicular lesions were characterized by subacute interstitial inflammatory processes with degenerative atrophy of the seminiferous epithelium (AMARA et al., 2009), which also was observed in this work.

Testicular degeneration may also be due to immunological factors. It is common to observe a significant inflammatory infiltrate in the testicles of symptomatic dogs, with a higher frequency of lymphocytes in the region, characterizing a local immune response (BENITES et al., 2011). The number of Leishmania amastigotes in the testicles acts as a triggering factor for the inflammatory response, whereas testicular degeneration may be a consequence of this inflammatory process (DINIZ et al., 2005). Therefore, Leishmania can accelerate the development of testicular changes.

\section{Conclusion}

In conclusion, parasitized dogs with VL have testicular lesions that may compromise the reproductive efficiency of these animals.

\section{Acknowledgments}

The authors thank the Zoonoses Control Department of Teresina, Piauí, Brazil; the Laboratory 
of Biotechnology Animal Reproduction; and the Animal Health Laboratory of the Federal University of Piauí by the acquisition, accommodation and accomplishment of the analyzes the animals.

\section{References}

ALLEN, J. A.; DIEMER, T.; JANUS, P.; HALES, K. H.; HALES, D. B. Bacterial endotoxin lipopolysaccharide and reactive oxygen species inhibit Leydig cell steroidogenesis via perturbation of mitochondria. Endocrine, Totowa, v. 25, n. 3, p. 265-275, 2004.

AMARA, A.; MRAD, I.; MELKI, M. K.; MRAD, M. B.; REJEB, A. Etude histologique dés lesions testiculaires chez les chiens leishmaniens. Revue de Médicine Vétérinaire, Toulose, v. 160, n. 1, p. 54-60, 2009.

BENITES, A. P.; FERNANDES, C. E.; BRUM, K. B.; ABDO, M. A. G. S. Presença de formas amastigotas de Leishmania chagasi e perfil leucocitário no aparelho reprodutivo de cães. Pesquisa Veterinária Brasileira, Seropédica, v. 31, n. 1, p. 72-77, 2011.

BOSCH, R. J.; RODRIGO, A. B.; SÁNCHEZ, P.; GÁLVEZ, M. V.; HERRERA, E. Presence of Leishmania organisms in specific and non-specific skin lesions in HIV- Infected individuals with visceral leishmaniasis. International Journal of Dermatology, Rochester, v. 41, n. 10, p. 670-675, 2002.

BRASIL. Ministério da Saúde. Secretaria de Vigilância em Saúde. Departamento de Vigilância Epidemiológica. Manual de vigilância e controle da leishmaniose visceral. $5^{a}$ reimpressão. Brasília: Ministério da Saúde, 2014. 120 p.

COSTA, V. N.; SOUSA FILHO, M. A. C.; SILVA, M. N. N.; MOTA, L. H. C. M.; CARVALHO, Y. N. T.; MELO EVANGELISTA, L. S. Níveis séricos de testosterona em cães naturalmente infectados por Leishmania sp. Ciência Animal, Fortaleza, v. 25, n. 1, p. 303-306, 2015. Suplemento.

DINIZ, S. A.; MELO, M. S.; BORGES, A. M.; BUENO, R.; REIS, B. P.; TAFURI, W. L.; NASCIMENTO, E. F.; SANTOS, R. L. Genital lesions associated with visceral leishmaniasis and shedding of Leishmania sp. in the semen of naturally infected dogs. Veterinary Pathology, Thousand Oaks, v. 42, n. 5, p. 650-658, 2005.

DUBEY, J. P.; ROSYPAL, A. C.; PIERCE, V.; SCHEINBERG, S. N.; LINDSAY, D. S. Placentitis associated with leishmaniasis in a dog. Journal of the American Veterinary Medical Association, Schaumburg, v. 227 , n. 8, p. 1266-1269, 2005.
FREITAS, E. de; MELO, M. N.; COSTA VAL, A. P. da; MICHALICK, M. S. Transmission of Leishmania infantum via blood transfusion in dogs: potential for infection and importance of clinical factors. Veterinary Parasitology, Amsterdam, v. 137, n. 1-2, p. 159-167, 2006.

HAFEZ, E. S. E.; HAFEZ, B. Reprodução animal. 7. ed. São Paulo: Manole, 2004. 513 p.

KAMHAWI, S. Phlebotomine sand flies and Leishmania parasites: friends or foes? Trends in Parasitology, Oxford, v. 22, n. 9, p. 439-445, 2006.

LOW, G. C.; EDIN, M. D.; LOND, F. R. C. P.; COOKE, W. E.; IREL, F. R. C. S. A. A congenital case of KalaAzar. The Lancet, London, v. 208, n. 5389, p. 1209-1211, 1926.

NUNES, R. R. M. Alterações genitais em animais reservatórios de tripanossomatídeos de importância para o produtor rural. 2008. Dissertação (Mestrado em Ciência Animal Tropical) - Universidade Federal do Tocantins, Araguaína.

PIARROUX, R.; AZAIEZ, R.; LOSSI, A. M.; REYNIER, P.; MUSCATELLI, F.; GAMBARELLI, M.; FONTES, M.; DUMONT, H.; QUILICI, M. Isolation and characterization of a repetitive DNA sequence from Leishmania infantum: development of a visceral leishmaniasis polymerase chain reaction. The American Journal of Tropical Medicine and Hygiene, Cleveland, v. 49, n. 3, p. 364-369, 1993.

SILVA, F. L.; OLIVEIRA, R. G.; SILVA, T. M. A.; XAVIER, M. N.; NASCIMENTO, E. F.; SANTOS, R. L. Venereal transmission of canine visceral leishmaniasis. Veterinary Parasitology, Amsterdam, v. 160, n. 1-2, p. 55-59, 2009.

SILVA, F. L.; RODRIGUES, A. A. M.; REGO, I. O. P.; SANTOS, R. L. H.; OLIVEIRA, R. G.; SILVA, T. M. A.; XAVIER, M. N.; NASCIMENTO, E. F.; SANTOS, R. L. Genital lesions and distribution of amastigotes in bitches naturally infected with Leishmania chagasi. Veterinary Parasitology, Amsterdam, v. 151, n. 1, p. 86-90, 2008.

SILVA, L. C.; ASSIS, V. P.; RIBEIRO, V. M.; TAFURI, W. L.; TOLEDO JÚNIOR, J. C.; SILVA, S. O.; MELO, M. N.; RACHID, M. A.; VALLE, G. R. Detection of Leishmania infantum in the smegma of infected dogs. Arquivo Brasileiro de Medicina Veterinária e Zootecnia, Belo Horizonte, v. 66, n. 3, p. 731-736, 2014.

SYMMERS, W. S. C. Leishmaniasis acquired by contagion: a case of marital infection in Britain. The Lancet, London, v. 275, n. 7116, p. 127-132, 1960. 